\title{
Hak Remisi Dan Asimilasi Narapidana Di Indonesia Dalam Perspektif Hak Asasi Manusia
}

\author{
Manggala Gita Arief Sulistiyatna \\ Magister Hukum Fakultas Hukum Universitas Islam Indonesia Yogyakarta Indonesia \\ Jln. Cik Di Tiro No. 1 Yogyakarta Indonesia \\ alliezmanggala@gmail.com
}

\begin{abstract}
This research aims to determine the regulation of remission and assimilation rights for prisoners in Indonesia, as well as the arrangement is ideal in the perspective of human rights. This is a normative juridical research that uses conceptual and statutory approaches. The results of the study show that the remission arrangement is still scattered in several rules and not in one comprehensive rule. The tightening by providing special conditions for prisoners of certain criminal acts in Article 34A of Government Regulation Number 99 of 2012 actually contains the problem of conflict between legal norms itself and there are also problems related to the loss of equal opportunity and equality before the law which is a human right that must be protected, including for prisoners. Strengthening the role of remission and assimilation is not only a right of prisoners, but also as a tool to provide motivation as well as appreciation for prisoners who have truly improved themselves. Therefore, there is a need for special rules governing remissions that cover all matters concerning remission, both the type of remission, the amount of remission, when it is given, the conditions and simple procedures and the authorized official to give it.
\end{abstract}

Key Words: Assimilation; human rights; remission

\begin{abstract}
Abstrak
Penelitian ini dilakukan untuk mengetahui pengaturan hak remisi dan asimilasi bagi narapidana di Indonesia, serta bagaimana pengaturannya yang ideal dalam perspektif hak asasi manusia. Penelitian ini merupakan penelitian yuridis normatif yang menggunakan metode pendekatan konspetual dan pendekatan perundang-undangan. Hasil penelitian menyimpulkan pengaturan remisi masih tersebar dalam beberapa aturan dan tidak menjadi satu aturan yang komprehensif. Pengetatan dengan pemberian syarat khusus terhadap narapidana tindak pidana tertentu dalam Pasal 34A Peraturan Pemerintah Nomor 99 Tahun 2012 justru mengandung masalah pertentangan antar norma hukum itu sendiri dan juga ada permasalahan terkait hilangnya kesempatan dan persamaan yang sama di depan hukum dimana hal tersebut merupakan hak asasi manusia yang harus dilindungi termasuk bagi narapidana. Penguatan peran remisi dan asimilasi bukan hanya sebagai hak narapidana, namun juga sebagai alat untuk memberikan motivasi sekaligus penghargaan bagi narapidana yang telah sungguhsungguh memperbaiki diri. Oleh karena itu, perlu aturan khusus yang mengatur tentang remisi yang mencakup seluruh hal tentang remisi baik jenis remisi, besaran remisi, kapan diberikannya, syaratsyaratnya serta prosedur sederhana dan pejabat yang berwenang memberikannya.
\end{abstract}

Kata-kata Kunci: Remisi; asimilasi; hak asasi manusia 


\section{Pendahuluan}

Sistem Peradilan Pidana merupakan sistem pengendalian kejahatan yang terdiri dari lembaga-lembaga kepolisian, kejaksaan, pengadilan, dan pemasyarakatan terpidana yang memiki tujuan untuk mencegah masyarakat menjadi korban kejahatan, menyelesaikan kasus kejahatan yang terjadi sehingga masyarakat puas bahwa keadilan telah ditegakkan dan yang bersalah dipidana, dan mengusahakan agar mereka yang pernah melakukan kejahatan tidak mengulangi lagi kejahatanya. ${ }^{1}$

Narapidana merupakan terpidana yang menjalani pidana hilang kemerdekaan di Lembaga Pemasyarakatan yang memiliki hak-hak yang dilindungi oleh hak asasi manusia dan Undang-Undang Republik Indonesia, salah satunya yaitu pemberian remisi oleh negara. Pada awalnya remisi atau pengurangan hukuman diberikan oleh pemerintah Kolonial Belanda sebagai anugerah kepada para tawanan perang dalam rangka merayakan ulang tahun Sri Ratu Belanda. Hal tersebut dicantumkan dalam Gouvernement Besluit 10 Agustus 1935 Nomor 23 Bijblad Nomor 13515 jo. 9 Juli 1841 Nomor 12 dan 26 Januari 1942 Nomor 22 tentang Remissieregeling yang kemudian diterapkan oleh Pemerintah Indonesia melalui Keputusan Presiden Republik Indonesia Serikat Nomor 156 Tahun 1950, 19 April 1950 tentang ampunan istimewa yang diberikan setiap Hari Ulang Tahun Kemerdekaan Republik Indonesia. ${ }^{2}$

Pengaturan mengenai remisi terdapat dalam Undang-Undang Nomor 12 Tahun 1995 tentang Pemasyarakatan, Peraturan Pemerintah Nomor 32 Tahun 1999 tentang Syarat dan Tata Cara Pelaksanaan Hak Warga Binaan Pemasyarakatan, dan Keputusan Presiden Nomor 174 Tahun 1999 tentang Remisi, serta kemudian perubahannya dalam Peraturan Pemerintah Nomor 99 Tahun 2012 yang merupakan perubahan kedua atas Peraturan Pemerintah 32 Tahun 1999 tentang Syarat dan Tata Cara Pelaksanaan Hak Warga Binaan Pemasyarakatan.

Pembahasan mengenai narapidana tidak bisa dipisahkan dari asimilasi narapidana sebagai bagian dari upaya mendekatkan atau membaurkan kembali kehidupan narapidana dengan masyarakat setelah sekian lama berada di dalam Lembaga Pemasyarakatan, melaksanakan pembinaan secara tertutup atau terpisah dari masyarakat luar sebelum benar-benar dilakukan integrasi yaitu dikembalikan lagi kepada masyarakat sebagaimana tujuan akhir dari system peradilan pidana melalui system pemasyarakatan. Asimilasi merupakan gerbang utama dalam tujuan sistem pemasyarakatan dan tentu guna mendapatkan bekal

${ }^{1}$ Luhut Pangaribuan, Hukum Acara Pidana: Surat Resmi Advokat di Pengadilan, Papas Sinar Sinanti, Jakarta, 2013, hlm. 14.

${ }^{2}$ Dwidja Priyatno, Sistem Pelaksanaan Pidana Penjara di Indonesia, PT. Refika Aditama, Bandung, 2006, hlm. 134. 
pelatihan kerja pasca asimilasi serta pembinaan kepribadian yang menunjukkan bahwa narapidana siap untuk kembali hidup bersama dengan masyarakat lagi.

Dalam perkembangannya, ada perbedaan pengaturan tentang hak remisi dan asimilasi narapidana bagi narapidana tindak pidana tertentu sebagaimana diatur dalam Peraturan Pemerintah Nomor 99 Tahun 2012 yang merupakan perubahan terhadap Peraturan Pemerintah Nomor 28 Tahun 2006 jo Peraturan Pemerintah 32 Tahun 1999 tentang Syarat dan Tata Cara Pelaksanaan Hak Warga Binaan Pemasyarakatan yang meliputi tindak pidana terorisme, narkotika dan prekursor narkotika, psikotropika, korupsi, kejahatan terhadap keamanan negara, kejahatan hak asasi manusia yang berat, serta kejahatan transnasional terorganisasi lainnya. Penentuan kapan asimilasi mulai dilaksanakan termasuk tata cara dan syarat-syarat lainnya sering kali juga membuat kecemburuan antar narapidana sehingga dirasakan kurang mencerminkan prinsip equality before the law atau kesamaan di muka hukum yang merupakan salah satu Hak Asasi Manusia yang tidak dapat dikurangi dalam keadaan apapun dan oleh siapapun sebagaimana diatur dalam Undang-Undang RI Nomor 39 Tahun 1999 tentang Hak Asasi Manusia.

Hak asasi manusia berarti membicarakan dimensi kehidupan manusia. Hak asasi manusia ada bukan disebabkan oleh masyarakat dan kebaikan dari negara, melainkan atas dasar martabatnya sebagai manusia. Pengakuan atas keberadaan manusia merupakan makhluk hidup ciptaan Tuhan Yang Maha Esa, patut memperoleh apresiasi secara positif. ${ }^{3}$ Hak asasi manusia adalah hak-hak dasar yang melekat pada jati diri manusia secara kodrati dan secara universal serta berfungsi menjaga integritas keberadaannya, berkaitan dengan hak hidup dan kehidupan, keselamatan, keamanan, kemerdekaan, keadilan, kebersamaan, kesejahteraan, dan hak untuk maju sebagai ciptaan Tuhan Yang Maha Esa yang tidak boleh diabaikan atau dirampas. ${ }^{4}$

Instrumen Internasional Hak Asasi Manusia Pasal 10 paragraf 3 International Covenant on Civil and Political Rights (ICCPR) menyatakan bahwa tujuan yang penting dari sistem pemasyarakatan/ penjara adalah reformasi dan rehabilitasi sosial dari tahanan. The Standard Minimum Rules for the Treatment of Prisoners (Mandela Rules) yang diadopsi oleh Kongres Perserikatan Bangsa-Bangsa yang Pertama tentang Pencegahan Kejahatan dan Perlakuan Pelaku Kejahatan, yang diadakan di Jenewa, Swiss, pada 1955, dan disetujui oleh Dewan Ekonomi dan Sosial melalui Resolusi 663 C (XXIV), 31 Juli 1957 dan Resolusi 2076 (LXII), 13 Mei

3 Jimly Asshiddiqie dan Hafid Abbas, Hak Asasi Manusia dalam Konstitusi Indonesia, Kharisma Putra Utama, Jakarta, Cetakan ke-5, 2015, hlm 1.

${ }^{4}$ M.Ali Zaidan, Menuju Perubahan Hukum Pidana, Sinar Grafika, Jakarta, 2015, hlm. 259. 
1977, juga mengamini tujuan untuk memfasilitasi rehabilitasi sosial dari pelaku tindak pidana.

Kajian hukum pidana, sistem pemasyarakatan, dan hak asasi manusia yang mana pemasyarakatan merupakan bagian dari sistem peradilan pidana terpadu sehingga pemasyarakatan menjadi bagian penting untuk mencapai tujuan akhirnya dalam Sistem Peradian Pidana Terpadu tersebut. Selain itu, kajian perlindungannya dalam hak asasi manusia merupakan hal utama dalam memandang keberhasilan pemasyarakatan sebagai kegiatan pembinaan dan sistem pemasyarakatan sebagai tatanan mengenai arah dan batas serta cara pembinaan warga binaan pemasyarakatan. Oleh karena itu, menjadikan penulis untuk tertarik membuat jurnal dengan judul "Hak Remisi dan Asimilasi Narapidana di Indonesia dalam Perspektif Hukum dan Hak Asasi Manusia".

\section{Rumusan Masalah}

Berdasarkan latar belakang di atas, rumusan masalah penelitian ini adalah sebagai berikut, pertama, bagaimana pengaturan dan realitas hak remisi dan asimilasi narapidana di Indonesia. Kedua, bagaimana pengaturan hak remisi dan asimilasi narapidana yang ideal dalam perspektif hak asasi manusia.

\section{Tujuan Penelitian}

Tujuan yang hendak dicapai melalui penelitian ini adalah untuk mengetahui pengaturan dan realitas hak remisi dan asimilasi bagi narapidana di Indonesia, serta yang seharusnya dalam perspektif hak asasi manusia.

\section{Metode Penelitian}

Penelitian ini merupakan penilitian hukum normatif dengan metode pendekatan konseptual dan perundang-undangan. Sumber data penelitian ini meliputi bahan hukum primer yang terdiri atas peraturan perundang-undangan yang berhubungan dengan pemidanaan/pemasyarakatan dan hak asasi manusia khususnya narapidana, dan bahan hukum sekunder yang berupa literaturliteratur dan karya ilmiah tentang ilmu hukum dan hak asasi manusia. Data penelitian tersebut diperoleh melalui studi kepustakaan dan studi dokumen yang kemudian dianalisis dengan analisis data kualitatif.

\section{Hasil Penelitian dan Pembahasan}

\section{Pengaturan Hak Remisi dan Asimilasi Narapidana di Indonesia}

Hak remisi bagi narapidana dicantumkan dalam Undang-Undang Nomor 12 Tahun 1995 yang menyatakan bahwa: "narapidana berhak mendapatkan pengurangan 
masa pidana (remisi)." Akan tetapi, Undang-Undang Pemasyarakatan tersebut tidak memberikan pengertian dan syarat serta tata cara bagaimana hak remisi narapidana tersebut diberikan sebagaimana dinyatakan dalam ayat (2) pasal tersebut yaitu "Ketentuan mengenai syarat-syarat dan tata cara pelaksanaan hak-hak Narapidana sebagaimana dimaksud dalam ayat (1) diatur lebih lanjut dengan Peraturan Pemerintah." 5

Bentuk pelaksanaan ketentuan di atas adalah dengan diterbitkannya Peraturan Pemerintah Nomor 32 Tahun 1999 tentang Syarat dan Tata Cara Pelaksanaan Hak Warga binaan Pemasyarakatan. Peraturan Pemerintah tersebut mendefinisikan remisi sebagai pengurangan masa menjalani pidana yang diberikan kepada Narapidana dan Anak Pidana yang memenuhi syarat-syarat yang ditentukan dalam peraturan perundang-undangan. Selanjutnya, pengaturan tentang pemberian remisi bagi narapidana diatur pada bagian kesembilan Pasal 34 sebagai berikut:

(1) Setiap Narapidana dan Anak Pidana yang selama menjalani masa pidana berkelakuan baik berhak mendapatkan remisi.

(2) Remisi sebagaimana dimaksud dalam ayat (1) dapat ditambah, apabila selama menjalani pidana, yang bersangkutan:

a. berbuat jasa kepada negara;

b. melakukan perbuatan yang bermanfaat bagi negara atau kemanusiaan; atau

c. melakukan perbuatan yang membantu kegiatan LAPAS.

(3) Ketentuan untuk mendapatkan remisi sebagaimana dimaksud dalam ayat (1) dan ayat (2) berlaku juga bagi Narapidana dan anak Pidana yang menunggu grasi sambil menjalani pidana. ${ }^{6}$

Sementara itu, ketentuan terkait jenis-jenis remisi dan kapan remisi tersebut dapat diberikan kepada narapidana diatur dalam Keputusan Presiden Republik Indonesia Nomor 174 Tahun 1999 tentang Remisi yaitu remisi umum dan remisi khusus. Selain itu, Keputusan Presiden Republik Indonesia Nomor 174 Tahun 1999 tentang Remisi menyebutkan bahwa: ${ }^{7}$

Remisi sebagaimana dimaksud dalam Pasal 2 dapat ditambah dengan remisi tambahan apabila Narapidana atau Anak Pidana yang bersangkutan selama menjalani pidana:

a. Berbuat jasa kepada negara;

b. Melakukan perbuatan yang bermanfaat bagi negara atau kemanusiaan; atau

c. Melakukan perbuatan yang membantu kegiatan pembinaan di Lembaga Pemasyarakatan.

\footnotetext{
${ }^{5}$ Pasal 14 ayat (1) Undang-Undang RI Nomor 12 Tahun 1995 tentang Pemasyarakatan.

${ }^{6}$ Pasal 34 Peraturan Pemerintah Nomor 32 Tahun 1999 Tentang Syarat dan Tata Cara Pelaksanaan Hak Warga Binaan Pemasyarakatan, Lembaran Negara Republik Indonesia Tahun 1999 Nomor 69, Tambahan Lembaran Negara Republik Indonesia Nomor 3846.

${ }^{7}$ Pasal 3 ayat (1) Keputusan Presiden Republik Indonesia Nomor 174 Tahun 1999 tentang Remisi.
} 
Pada awalnya, peraturan tentang remisi tersebut bersifat umum yaitu tidak membedakan kualifikasi tindak pidana yang pernah dilakukan bagi narapidana. Akan tetapi, dalam perkembangannya syarat remisi tersebut diubah sebagaimana diatur dalam Peraturan Pemerintah Nomor 99 Tahun 2012 tentang Perubahan Kedua Atas Peraturan Pemerintah Nomor 32 Tahun 1999 tentang Syarat dan Tata Cara Pelaksanaan Hak Warga binaan Pemasyarakatan. Pengubahan yang dimaksud adalah adanya penambahan syarat remisi diperuntukkan bagi narapidana yang dipidana karena melakukan tindak pidana terorisme, narkotika dan psikotropika, korupsi, kejahatan terhadap keamanan negara dan kejahatan hak asasi manusia yang berat, dan kejahatan transnasional terorganisasi lainnya. Adapun syarat tambahan tersebut tercantum dalam Pasal 34A Peraturan Pemerintah Nomor 99 Tahun 2012 yaitu sebagai berikut:

a. Bersedia bekerjasama dengan penegak hukum untuk membantu membongkar perkara tindak pidana yang dilakukannya;

b. Telah membayar lunas denda dan uang pengganti sesuai dengan putusan pengadilan untuk narapidana yang dipidana karena melakukan tindak pidana korupsi; dan

c. Telah mengikuti program deradikalisasi yang diselenggarakan oleh lapas dan/atau badan nasional penanggulangan terorisme, serta menyatakan ikrar:

1) Kesetiaan kepada negara kesatuan republik indonesia secara tertulis bagi narapidana warga negara indonesia, atau

2) Tidak akan mengulangi perbuatan tindak pidana terorisme secara tertulis bagi narapidana warga negara asing, yang dipidana karena melakukan tindak pidana terorisme.

Jenis-jenis remisi menurut Peraturan Menteri Hukum dan Hak Asasi Manusia Nomor 3 Tahun 2018 sebagaimana diubah dengan Peraturan Menteri Hukum dan Hak Asasi Manusia Nomor 18 Tahun 2019 tentang Syarat dan Tata Cara Pemberian Remisi, Asimilasi, Cuti Mengunjungi Keluarga, Pembebasan Bersyarat, Cuti Menjelang Bebas, dan Cuti Bersyarat, yaitu remisi umum, remisi khusus, remisi kemanusiaan, remisi tambahan, dan remisi susulan, serta remisi perubahan pidana seumur hidup menjadi sementara waktu dan remisi atas kejadian luar biasa seperti bencana alam. Remisi umum yaitu remisi yang diberikan pada saat hari peringatan Proklamasi Kemerdekaan Republik Indonesia 17 Agustus sedangkan remisi khusus yaitu remisi yang diberikan pada saat hari besar keagamaan yang dianut oleh Narapidana atau Anak yang bersangkutan.

Penelusuran peraturan-peraturan yang mengatur berbagai jenis remisi bagi narapidana menunjukkan bahwa pengaturan remisi tidak terkodifikasi dalam satu peraturan yang sistematis, tetapi tersebut di beberapa peraturan yaitu sebagai berikut: 
1) Remisi yang diatur di dalam Kepres No. 174 Tahun 1999 dan Permenkumham No. 3 Tahun 2018 sebagaimana diubah dalam Pemenkumham No. 18 Tahun 2019 yaitu remisi umum, remisi khusus, dan remisi tambahan.

2) Remisi yang di atur di dalam Permenkumham No. 3 Tahun 2018 sebagaimana diubah dalam Pemenkumham No. 18 Tahun 2019 yaitu remisi susulan, kemanusiaan dan tambahan.

3) Remisi yang hanya diatur di dalam Kepres No. 174 Tahun 1999 yaitu remisi perubahan pidana seumur hidup menjadi pidana sementara waktu (maksimal 15 tahun).

4) Remisi yang hanya diatur di dalam Kepres No. 120 Tahun 1955 yaitu remisi dasawarsa.

5) Remisi yang diberikan atas kejadian luar biasa, antara lain bencana alam berupa gempa bumi dan tsunami di Aceh berdasarkan Kepres No. 21 Tahun 2005.

Sementara itu, Asimilasi merupakan hak yang diberikan kepada narapidana yang dituangkan dalam Undang-Undang Nomor 12 Tahun 1995 tentang Pemasyarakatan yaitu dalam Pasal 14 ayat (1) huruf j sebagai berikut: "narapidana berhak mendapatkan kesempatan berasimilasi termasuk cuti mengunjungi keluarga." Asimilasi merupakan bagian dari pembinaan ekstramural (diluar lapas) sebagaimana dinyatakan dalam penjelasan Pasal 6 ayat (1) yang menyebutkan bahwa, "Pembinaan Warga Binaan Pemasyarakatan di LAPAS dilaksanakan secara intramural (di dalam LAPAS) dan secara ekstramural (di luar LAPAS). Pembinaan secara ekstramural yang dilakukan di LAPAS disebut asimilasi, yaitu proses pembinaan Warga Binaan Pemasyarakatan yang telah memenuhi persyaratan tertentu dengan membaurkan mereka ke dalam kehidupan masyarakat."

Pengaturan lebih lanjut mengenai asimilasi narapidana diatur dalam Peraturan Pemerintah Nomor 31 Tahun 1999 tentang Pembinaan dan Pembimbingan Warga Binaan Pemasyarakatan, dimana pengertian asimilasi dinyatakan dalam Pasal 1 angka (9) sebagai berikut, "Asimilasi adalah proses pembinaan Narapidana dan Anak Didik Pemasyarakatan yang dilaksanakan dengan membaurkan Narapidana dan Anak Didik Pemasyarakatan dalam kehidupan masyarakat." Selain asimilasi sebagai hak narapidana, asimilasi juga merupakan bagian dari tahapan pembinaan narapidana itu sendiri yaitu pada tahap lanjutan atau setengah dari masa pidana penjara yang dijalani.

Sebagaimana juga terjadi pada pengaturan remisi, pengaturan asimilasi bagi narapidana juga mengalami perubahan sebagaimana diatur dalam Peraturan Pemerintah Nomor 99 Tahun 2012 tentang Perubahan Kedua Perubahan Kedua Atas Peraturan Pemerintah Nomor 32 Tahun 1999, dimana waktu pelaksanaan asimilasi khusus untuk narapidana yang dipidana karena melakukan tindak 
pidana terorisme, narkotika dan prekursor narkotika, psikotropika, korupsi, kejahatan terhadap keamanan negara dan kejahatan hak asasi manusia yang berat, serta kejahatan transnasional terorganisasi lainnya adalah telah menjalani 2/3 masa pidana dengan paling singkat 9 bulan, dan bagi narapidana yang dipidana karena tindak pidana korupsi juga harus membayar lunas denda dan/atau uang pengganti sesuai dengan putusan pengadilan serta dilaksanakan dalam bentuk kerja sosial pada lembaga sosial baik lembaga pemerintah maupun yang dibentuk masyarakat.

Ketentuan tambahan syarat berupa lunas membayar denda dan uang pengganti untuk dapat diberikannya hak remisi dan asimilasi bagi narapidana tersebut justru menimbulkan pertentangan antar norma hukum, dimana secara yuridis dapat dikaji sebagai berikut:

a. Denda adalah pidana pokok dalam Pasal $10 \mathrm{KUHP}$, dimana dalam Pasal 30 ayat (2) KUHP dinyatakan tegas bahwa pidana denda apabila tidak dibayar diganti dengan pidana kurungan, paling lama 6 bulan $^{8}$ atau untuk tindak pidana narkotika diganti penjara paling lama 2 tahun. ${ }^{9}$ Atas dasar hukum tersebut jelas bahwa membayar denda atau menjalani pidana penggantinya adalah pilihan hak dari terpidana yang dilindungi oleh hukum, tidak dapat dipaksa karena bukan kewajiban. Setiap terpidana berhak untuk membayar denda atau memilih menjalani pidana kurungan pengganti denda.

b. Uang Pengganti adalah pidana tambahan dalam Pasal 18 Undang-Undang Nomor 31 Tahun 1999 sebagaimana diubah dengan Undang-Undang Nomor 20 Tahun 2001 tentang Pemberantasan Tindak Pidana Korupsi. Pasal tersebut mengatur bahwa apabila uang pengganti tidak dibayar dalam waktu satu bulan Jaksa sebagai eksekutor menyita harta bendanya dan dilelang untuk menutupi uang pengganti tersebut, jika harta bendanya tidak mencukupi maka dipidana dengan pidana penjara penggantinya yang lamaya ditentukan dalam putusan pengadilan. Artinya, jika uang pengganti tidak terbayar telah ada mekanismenya, yaitu setelah harta bendanya ditelusuri Jaksa ternyata tidak mencukupi artinya terpidana tidak berkemampuan untuk membayar uang pengganti, maka baik undang-undang maupun putusan pengadilan membebaninya dengan pidana penjara penggantinya.

c. Putusan pengadilan yang telah berkekuatan tetap telah menyebut pidana denda apabila tidak dibayar diganti dengan pidana kurungan, sedangkan uang pengganti apabila harta benda terpidana tidak cukup maka diganti pidana penjara pengganti sesuai dalam putusan tersebut.

\footnotetext{
${ }^{8}$ Pasal 30 ayat (3) Kitab Undang-Undang Hukum Pidana (KUHP).

${ }_{9}^{9}$ Pasal 148 Undang-Undang Nomor 35 Tahun 2009 tentang Narkotika.
} 
Pernyataan di atas menunjukkan bahwa dalam perspektif hukum, membayar denda atau menjalani kurungan pengganti adalah hak terpidana untuk memilihnya, bukan kewajiban membayar, bahkan telah dipertegas dalam Putusan Pengadilan itu sendiri. Akan tetapi, justru Peraturan Pemerintah Nomor 99 Tahun 2012 mewajibkan terpidana untuk membayar denda tersebut untuk dapat memperoleh haknya mendapatkan remisi. Peraturan tersebut jelas mengubah hak menjadi kewajiban, sehingga secara yuridis terdapat pertentangan hukum antara KUHP didukung putusan pengadilan dengan Peraturan Pemerintah Nomor 99 Tahun 2012 itu sendiri.

Kewajiban membayar uang pengganti dalam Peraturan Pemerintah Nomor 99 Tahun 2012 sebagai syarat wajib memperoleh hak remisi, terpidana yang tidak membayar uang pengganti tersebut berdasarkan undang-undang dan putusan pengadilan jelas harta bendanya tidak mencukupi setelah ditelusuri oleh Jaksa selaku eksekutor, sehingga bebannya berdasarkan hukum ditambah dengan pidana penjara pengganti. Hal ini berarti berdasarkan hukum, orang yang tidak mampu membayar uang pengganti setelah hartanya ditelusuri oleh Jaksa ternyata hartanya tidak cukup, justru tetap diwajibkan membayar uang pengganti sebagai syarat mendapatkan hak remisi tersebut, hal ini jelas tidak sesuai dengan undangundang maupun putusan pengadilan itu sendiri.

Sementara syarat lain untuk mendapatkan remisi adalah bersedia bekerjasama dengan penegak hukum untuk membongkar tindak pidana yang dilakukannya sebagaimana dalam Peraturan Pemerintah Nomor 99 Tahun 2012 juga membuat masalah hukum. Secara yuridis hal ini membingungkan mengingat korupsi, narkotika dan tidak pidana lainnya ada yang sederhana dan tidak memerlukan peran tersangka/terdakwa untuk membongkar tindak pidana tersebut sehingga tidak ada kesempatan menjadi Justice Collaborator (saksi pelaku yang bekerjasama). Namun, meskipun ada kesempatan menjadi Justice Collaborator, maka sesuai dengan surat edaran Mahkamah Agung RI, kepentingan Justice Collaborators tersebut ada dalam persidangan (ajudikasi) yaitu diberikan pidana yang paling ringan diantara pelaku yang lainnya. ${ }^{10}$

Peraturan Pemerintah Nomor 99 Tahun 2012 tersebut justru menggunakan syarat remisi terhadap tindak pidana tertentu tersebut pada tahap post-ajudikasi yaitu saat narapidana sebagai subjek dalam pembinaan narapidana dalam Lembaga Pemasyarakatan dengan mewajibkan sebagai bekerja sama dengan penegak hukum atau Saksi Pelaku Yang Bekerjasama (Justice Collaborators).

10 Surat Edaran Mahkamah Agung RI Nomor 4 Tahun 2011 tentang Perlakuan bagi Pelapor Tindak Pidana (Wistleblower) dan Saksi Pelaku yang Bekerjasama (Justice Collaborators) di dalam Perkara Tindak Pidana Tertentu. 
Padahal fungsi Justice Collaborators ditetapkan untuk proses persidangan dimana putusannya lebih rendah dari pelaku lain sesuai Surat Edaran Mahkamah Agung RI Nomor 4 Tahun 2011, bukan sebagai syarat remisi, dan tidak setiap perkara tersebut membutuhkan Justice Collaborators untuk mengungkap tindak pidana.

Tiga masalah tersebut yaitu wajib membayar denda, uang pengganti, dan bekerjasama dengan penegak hukum sebagai Justice Collaborators menimbulkan masalah besar dalam sistem pemasyaratan yang memberikan hak narapidana untuk memperbaiki diri dengan aktif mengikuti program pembinaan narapidana di dalam Lembaga Pemasyaratan karena tidak mendapatkan hak remisi sebagai motifasi sekaligus penghargaan sebagai pribadi yang baik dan siap umtuk kembali ke lingkungan masyarakat kembali.

Persoalan hukum berlakunya syarat remisi bagi tindak pidana tertentu dalam Pasal 34A Peraturan Pemerintah Nomor 99 Tahun 2012 tersebut membuat perlakuan hukum pemberian hak yang tidak sama dengan narapidana lainnya. Hal tersebut justru bertentangan dengan hak asasi manusia berupa hak untuk diperlakukan sama di depan hukum yaitu:

a. Pasal 27 ayat (1) Undang-Undang Dasar Tahun 1945 menyatakan bahwa "Segala warga negara bersamaan kedudukannya di dalam hukum dan pemerintahan dan wajib menjunjung hukum dan pemerintahan itu dengan tidak ada kecualinya."

b. Pasal 3 ayat (2) Undang-Undang RI Nomor 39 Tahun 1999 menyatakan bahwa: "Setiap orang berhak atas pengakuan, jaminan, perlindungan dan perlakuan hukum yang adil serta mendapat kepastian hukum dan perlakuan yang sama di depan hukum.

c. Pasal 26 Undang-Undang RI Nomor 12 Tahun 2005 tentang Pengesahan International Covenant On Civil And Political Rights (Kovenan Internasional Tentang Hak-Hak Sipil Dan Politik) menyatakan bahwa : "Semua orang berkedudukan sama di hadapan hukum dan berhak atas perlindungan hukum yang sama tanpa diskriminasi apapun."

Pemaparan di atas menunjukkan bahwa pengetatan syarat yang dilakukan untuk narapidana tindak pidana tertentu menghambat pemberian remisi dan asimilasi hingga integrasi berupa pembebasan bersyarat, cuti menjelang bebas serta cuti bersyarat hal mana merupakan tahapan penyatuan kembali narapidana kepada masyarakat sebagaimana tujuan yang diinginkan oleh system pemasyarakatan sebagai system yang telah disepakati untuk pembinaan narapidana. Sistem penyatuan kembali narapidana dengan masyarakat secara bertahap juga diadopsi oleh Standard Minimum Rules for the Treatment of Prisoners (Aturan Minimum Standar tentang Penanganan Tahanan) dinyatakan sebagai berikut khususnya dalam Pasal 60 ayat (2) yang menyatakan secara lengkap sebagai berikut : 
"Before the completion of the sentence, it is desirable that the necessary steps be taken to ensure for the prisoner a gradual return to life in society. This aim may be achieved, depending on the case, by a pre-release regime organized in the same institution or in another appropriate institution, or by release on trial under some kind of supervision which must not be entrusted to the police but should be combined with effective social aid. (Sebelum masa pidana penjara selesai dijalani, akan bermanfaat jika diambil langkah-langkah yang diperlukan untuk memastikan kembalinya narapidana yang bersangkutan secara gradual ke dalam kehidupan bermasyarakat. Tergantung pada kasusnya, tujuan ini bisa diwujudkan melalui penggunaan sebuah rezim prapembebasan yang diselenggarakan di lembaga penjara yang bersangkutan atau di lembaga lain yang tepat atau melalui penggunaan pembebasan bersyarat dengan pengawasan tertentu yang tidak boleh dipercayakan kepada kepolisian tetapi perlu dikombinasikan dengan bantuan sosial yang efektif).

International Covenant on Civil And Political Rights (Kovenan Internasional Tentang Hak-Hak Sipil Dan Politik) atau ICCPR yang telah diratifikasi oleh negara Indonesia menyatakan bahwa11 :

1. Semua orang yang dirampas kebebasannya harus diperlakukan secara manusiawi dan dengan menghormati martabat yang melekat pada umat manusia.

2. (a) Para terdakwa, kecuali dalam keadaan yang sangat khusus harus dipisahkan dari para narapidana dan harus mendapatkan perlakuan tersendiri sesuai dengan statusnya sebagai orang-orang yang bukan narapidana.

(b) Para terdakwa yang masih di bawah umur harus dipisahkan dan secepat mungkin dibawa ke sidang pengadilan.

3. Sistem penjara harus mempunyai tujuan utama reformasi dan rehabilitasi sosial dalam perlakuan terhadap narapidana. Para pelanggar hukum yang masih di bawah umur harus dipisahkan dari orang dewasa dan diberikan perlakuan yang sesuai dengan usia dan status hukum mereka.

Pasal 10 tersebut telah sesuai dengan tujuan dari sistem pemasyarakatan yang tercantum dalam Pasal 2 Undang-Undang Pemasyarakatan yaitu, "Sistem pemasyarakatan diselenggarakan dalam rangka membentuk Warga Binaan Pemasyarakatan agar menjadi manusia seutuhnya, menyadari kesalahan, memperbaiki diri, dan tidak mengulangi tindak pidana sehingga dapat diterima kembali oleh lingkungan masyarakat, dapat aktif berperan dalam pembangunan, dan dapat hidup secara wajar sebagai warga yang baik dan bertanggung jawab." Jadi, Undang-Undang Pemasyarakatan merupakan perwujudan perlindungan hak asasi manusia bagi narapidana sehingga hak-hak narapidana yang diberikan berdasarkan undangundang tersebut merupakan perwujudan pengakuan harkat dan martabat narapidana sebagai manusia yang harus dihormati dan dilindungi. Terkait hal ini,

11 Pasal 10 Undang-Undang RI Nomor 12 Tahun 2005 tentang Hak-Hak Sipil dan Politik. 
Pasal 3 Body of Principles for the Protection of All Persons under Any Form of Detention or Imprisonment Adopted by General Assembly resolution 43/173 of 9 December 1988 menyatakan sebagai berikut:

"There shall be no restriction upon or derogation from any of the human rights of persons under any form of detention or imprisonment recognized or existing in any State pursuant to law, conventions, regulations or custom on the pretext that this Body of Principles does not recognize such rights or that it recognizes them to a lesser extent." (Tidak akan ada pembatasan atau pengurangan dari salah satu hak asasi manusia orang dengan segala bentuk penahanan atau pemenjaraan yang diakui atau ada di Negara mana pun sesuai dengan hukum, konvensi, peraturan atau kebiasaan dengan dalih bahwa Badan Prinsip ini tidak mengakui hak-hak tersebut atau bahwa ia mengenali mereka pada tingkat yang lebih rendah).

Remisi sebagai salah satu hak yang diberikan kepada narapidana merupakan konsekuensi dari sistem pemasyarakatan yang diterapkan untuk pembinaan narapidana sesuai dengan tujuan pemidanaan dan sistem peradilan pidana yaitu mengupayakan orang yang bersalah agar memperbaiki diri dan tidak mengulangi tindak pidananya. Pemotongan masa hukuman bagi narapidana yang menunjukkan telah memperbaiki diri dengan perilaku yang baik serta aktif mengikuti program pembinaan narapidana jelas merupakan penghargaan harkat dan martabatnya sebagai manusia. Semakin dirinya memperbaiki diri dan memperlihatkan perilaku sosial yang baik dengan kegiatan-kegiatan yang berguna bagi manusia lainnya termasuk juga bagi kepentingan Lembaga Pemasyarakatan maka kesempatan untuk memperoleh potongan masa hukuman bertambah karena adanya remisi tambahan yang dapat diberikan.

Banyak sisi kemanusiaan yang dijadikan dasar pemberian remisi sebagai perlindungan hak asasi manusia, antara lain remisi lansia (lanjut usia) yang diberikan pada narapidana yang telah berusia 70 tahun ke atas maupun remisi bagi narapidana yang menderita sakit berkepanjangan sulit untuk disembuhkan, yang diderita mengancam jiwa atau nyawa dan selalu mendapat perawatan ahli atau dokter sepanjang hidupnya. Selain itu, Standard Minimum Rules for the Treatment of Prisoners maupun Body of Principles for the Protection of All Persons under Any Form of Detention or Imprisonment juga menunjukan perhatian terhadap narapidana yang sakit maupun yang telah lanjut usia serta terhadap anak-anak.

Ketentuan tersebut menunjukan bahwa orang-orang yang rentan meskipun berstatus sebagai narapidana tetap diperhatikan secara khusus dan mendapatkan perlindungan karena rasa kemanusian terhadap sesama manusia. Namun alasan kemanusiaan tersebut juga tidak dapat diberikan kepada narapidana tindak pidana korupsi jika tidak memenuhi syarat sebagaimana di atas yaitu membayar 
lunas denda dan uang pengganti serta sebagai Justice Collaborator atau bekerjasama dengan penegak hukum, hal mana telah diuraikan di atas mengandung pertentangan norma hukum. Oleh karena itu, ada golongan narapidana tertentu yang tidak mendapatkan kesempatan yang sama dan diperlakukan sama di muka hukum, apalagi yang alasan kemanusiaan yang sangat manusiawi sekalipun, tetap tidak dapat diberikan sehingga hak untuk diakui harkat dan martabatnya sebagai manusia sebagai hak asasi manusia dapat terlanggar, bahkan oleh aturan hukum sendiri.

Narapidana juga manusia sehingga berhak hidup dan mempertahankan kehidupannya sehingga pengecualian pemberian remisi alasan kemanusiaan bagi narapidana tertentu sangat tidak manusiawi. Pada saat terjadi Pandemi Covid-19, Kementrian Hukum dan Hak Asasi Manusia menerbitkan Keputusan tentang Syarat Pembebasan Asimilasi dan Hak Integrasi Bagi Narapidana dan Anak Dalam Rangka Pencegahan dan Penanggulangan Penyebaran Covid-19.12 Kebijakan tersebut didasarkan pada rekomendasi United Nations Human Rights (UNHR) atau Dewan Hak Asasi Manusia Perserikatan Bangsa-Bangsa yang merupakan organisasi penerus dari Komisi Hak Asasi Manusia PBB, dan diterapkan di banyak negara terutama yang mengalami over kapasitas narapidana seperti di Indonesia, karena mustahil menerapkan social distancing di dalam Lembaga Pemasyarakatan.

Kebijakan yang sangat manusiawi tersebut sesuai dengan d dengan dengan UUD 1945 pada Pasal 28A UUD 1945 yang menyatakan bahwa, “Setiap orang berhak untuk hidup serta berhak mempertahankan hidup dan kehidupannya" dan Undang-Undang Hak Asasi Manusia pada Bab III Hak Asasi Manusia dan Kebebasan Dasar Manusia, Bagian Kesatu, Hak untuk Hidup yaitu Pasal 9 ayat (1) juga dinyatakan bahwa, "Setiap orang berhak untuk hidup, mempertahankan hidup dan meningkatkan taraf kehidupannya." serta dalam Undang-Undang RI Nomor 12 tahun 2005 tentang Pengesahan International Covenant on Civil and Political Rights (Kovenan Internasional Tentang Hak-Hak Sipil dan Politik) pada Pasal 6 menyatakan, "Setiap manusia berhak atas hak untuk hidup yang melekat pada dirinya. Hak ini wajib dilindungi oleh hukum. Tidak seorang pun dapat dirampas hak hidupnya secara sewenang-wenang."

Kebijakan atas dasar kemanusiaan dan menyangkut hak hidup dan mempertahankan kehidupan itu juga dikecualikan untuk narapidana tertentu narapidana tindak pidana terorisme, narkotika dan psikotropika, korupsi,

12 Keputusan Menteri Hukum dan HAM Nomor 10 Tahun 2020 tentang Syarat Pembebasan Asimilasi dan Hak Integrasi Bagi Narapidana dan Anak Dalam Rangka Pencegahan dan Penanggulangan Penyebaran Covid-19. 
kejahatan terhadap keamanan negara dan kejahatan hak asasi manusia yang berat, dan kejahatan transnasional terorganisasi dan warga Negara asing, bahkan lebih dari itu, narapidana yang memenuhi syarat seperti membayar denda dan uang pengganti serta sebagai Justice Collaborator sekalipun tetap dikecualikan sehingga terlihat jelas membedakan kesempatan dan perlakuan di hadapan hukum, padahal hal itu merupakan hak asasi manusia yang tidak dapat dikurangi dalam keadaan apapun dan oleh siapapun.

\section{Pengaturan Hak Remisi dan Asimilasi Narapidana yang Ideal dalam Perspektif Hak Asasi Manusia}

Hak Asasi Manusia sebagai hak mendasar manusia termasuk narapidana sebagai seorang yang tersesat dan sedang memperbaiki diri dalam Lembaga Pemasyarakatan perlu dilindungi dengan menerjemahkan hak asasi tersebut dalam bentuk hak-hak narapidana termasuk hak remisi. Pengaturan remisi yang tidak dalam satu aturan akan mudah dipahami secara keliru oleh masyarakat, khususnya bagi yang belum memahami apa tujuan pemidanaan dan pelaksanaannya dengan sistem pemasyarakatan mengingat sebagian masyarakat masih memiliki pola pikir bahwa orang yang bersalah harus diganjar dengan pidana karena kesalahannya tersebut (absolut theory) sehingga remisi justru dianggap bertentangan dengan keadilan yang dipahami secara sempit sebagai pembalasan.

Pengaturan remisi yang tersebar di beberapa aturan tersebut seyogyanya diubah untuk memudahkan pemahaman dan pelaksanaan sekaligus sebagai landasan utama pemberian remisi bagi narapidana dengan menjadikannya satu aturan utama misalnya dalam bentuk Peraturan Pemerintah. Peraturan Pemerintah khusus tentang remisi tersebut dapat dilakukan dengan mengubah undang-undang sebelumnya yaitu Undang-Undang RI Nomor 12 Tahun 1995 tentang Pemasyarakatan mengingat terbitnya Peraturan Pemerintah tentu harus dinyatakan dalam undang-undang tersebut. Sementara itu, Undang-Undang Pemasyarakatan saat ini hanya menyebut Peraturan Pemerintah yang merangkum semua hak-hak narapidana dalam satu aturan yaitu Peraturan Pemerintah Nomor 32 Tahun 1999 sebagaimana telah diubah yang kedua yatu Peraturan Pemerintah Nomor 99 Tahun 2012 tentang Syarat Dan Tata Cara Pemberian Hak Warga Binaan Pemasyarakatan. Jadi, peraturan tersebut perlu diubah karena pengaturan remisi sangat kompleks dan terdiri atas banyak jenis dengan syarat-syarat tertentu.

Pengkodifikasian pengaturan remisi dalam suatu aturan tersebut akan mewujudkan kepastian hukum karena menghilangkan ketentuan remisi yang hanya diatur dalam Keputusan Presiden tetapi tidak ada dalam Peraturan 
Menteri Hukum dan Hak Asasi Manusia dan Peraturan Pemerintah ataupun sebaliknya sebagaimana terjadi saat ini. Kepastian hukum tersebut akan mampu menjamin hak diperlakukan sama di depan hukum (equality before the law) ataupun kesempatan yang sama di depan hukum (right of legal equality) hal mana merupakan hak asasi manusia yang tidak dapat dikurangi dalam keadaan apapun dan oleh siapapun.

Pengaturan pemberian hak remisi pada narapidana yang ideal dan selaras dengan hak asasi manusia dapat terwujud selama remisi benar-benar dijadikan alat untuk memberikan motivasi pada narapidana untuk memperbaiki diri dan aktif mengikuti program pembinaan narapidana dengan baik serta penghargaan terhadap narapidana yang melakukan tindakan tambahan yang ditujukan dengan kepedulian terhadap kemanusiaan juga terhadap kepentingan bangsa dan negara. Penulis lebih cenderung membagi pemberian remisi menjadi 2 bagian sebagai berikut:

a. Remisi umum dan remisi khusus

Remisi ini diberikan sejak awal kepada narapidana yang masuk dalam Lembaga Pemasyaratan sebagai motivator. Hal ini mirip seperti sistem kredit remisi di Amerika, bedanya sistem ini diterapkan untuk remisi umum dan khusus yang sejak awal sebenarnya telah dapat diperhitungkan jumlah remisi yang akan diberikan pada narapidana karena 17 Agustus dan hari besar agama yang akan dilewati oleh narapidana selama dalam Lembaga Pemasyarakatan dapat diketahui sejak awal. Selanjutnya, potongan hukuman dalam bentuk remisi tersebut dapat berkurang mana kala narapidana melakukan pelanggaran atau tidak aktif mengikuti program pembinaan dengan baik.

b. Remisi tambahan dan remisi lainnya.

Remisi ini tidak diberikan di awal masuknya narapidana dalam Lembaga Pemasyarakatan, namun diberikan sesuai dengan kondisi berdasarkan perkembangan pembinaan dan perilaku narapidana apakah layak diberikan atau tidak didasarkan pada usulan Kepala Lembaga Pemasyarakatan atas rekomendasi independen dari Tim Pengamat Pemasyarakatan. Remisi karena berbuat jasa pada negara atau kemanusiaan misalnya, remisi ini diberikan apabila memang secara sukarela narapidana berbuat jasa kemanusiaan atau pada negara seperti donor darah rutin, donor anggota tubuh, menjadi pemuka narapidana membantu dalam program pembinaan atau jasa lainnya sebagaimana dalam ketentuan yang sebelumnya telah ada.

Penempatan remisi pada dua posisi tersebut menjadikan peran remisi benarbenar akan terlihat sebagai stimulus narapidana untuk berupaya memperbaiki diri dan semakin layak untuk segera kembali ke tengah masyarakat. Oleh karena 
itu, remisi akan menjadi peran terbaik dalam posisi penting menentukan keberhasilan pembinaan narapidana dengan sistem pemasyarakatan.

Pengaturan remisi yang berperspektif hak asasi manusia dapat terwujud apabila menunjukkan perhormatan harkat dan martabat manusia yang telah sungguh-sungguh memperbaiki diri dalam Lembaga Pemasyarakatan serta hak mendapatkan kesempatan yang sama dan diperlakukan sama di depan hukum sebagaimana dalam Pasal 26 International Covenant On Civil And Political Rights (Kovenan Internasional Tentang Hak-Hak Sipil Dan Politik) atau ICCPR yang telah diratifikasi oleh negara Indonesia dalam Undang-Undang Nomor 12 Tahun 2005 berupa "Semua orang berkedudukan sama di hadapan hukum dan berhak atas perlindungan hukum yang sama tanpa diskriminasi apapun." Jadi, ada beberapa poin yang diperlukan agar pengaturan remisi berspektif hak asasi manusia, yaitu:

a. Menguatkan peran dan posisi remisi dalam proses pembinaan narapidana sebagai hak yang melekat sejak awal atau diberikan sejak awal untuk semua narapidana berupa remisi umum dan khusus. Remisi tersebut dapat bertambah dengan remisi tambahan jika melakukan kegiatan untuk kepentingan kemanusian, bangsa dan negara yang telah ditentukan diberitahukan sejak awal sebagai tambahan motivasi atau justru remisi tersebut berkurang jika melakukan pelanggaran atau tidak mengikuti program pembinaan yang telah diprogramkan untuk dirinya sebagai narapidana. Sehingga benar-benar nasib mereka diserahkan pada diri mereka sendiri.

b. Menggunakan remisi untuk mengurangi masa hukuman narapidana oleh negara dengan alasan kemanusiaan antara lain narapidana yang telah lanjut usia atau menderita sakit yang berkepanjangan atau harapan hidupnya rendah tanpa membedakan latar belakang tindak pidana yang pernah dilakukannya. Membedakan latar belakang kasus untuk alasan kemanusiaan ini sangat tidak manusiawi, apalagi mereka yang benar-benar telah memperbaiki diri dalam Lembaga Pemasyarakatan.

c. Menghapus syarat-syarat khusus yang melihat latar belakang tindak pidana dari narapidana, ${ }^{13}$ seperti membayar lunas denda dan uang pengganti serta status Justice Collaborator yang membuat terjadinya pertentangan aturan hukum. Terkait syarat wajib menyatakan ikrar setia terhadap Negara Kesatuan Republik Indonesia tetap diwajibkan bagi narapidana terorisme mengingat ikrar tersebut menunjukan kesediaan narapidana teorisme untuk dibina serta menunjukan bahwa benar-benar telah menyadari kesalahannya, karena bersedia untuk dibina atau mengikuti pembinaan adalah syarat wajib

\footnotetext{
${ }_{13}$ Peraturan Pemerintah Nomor 32 Tahun 1999 tentang Syarat dan Tata Cara Pelaksanaan Hak Warga Binaan Pemasyarakatan.
} 
pemberian remisi bagi narapidana, jika tidak bersedia menandatangani ikrar tersebut artinya narapidana kasus terorisme tidak bersedia untuk di bina dalam Lembaga Pemayarakatan yang berlandaskan Pancasila dan UndangUndang Dasar 1945.

d. Pengaturannya remisi yang ada saat ini tersebar dalam berbagai aturan tersebut, perlu di kodifikasi menjadi satu aturan mengenai remisi untuk mengurangi potensi pelanggaran hak asasi manusia diperlakukan yang sama dan diberi kesempatan yang sama, dalam hal ini adalah hak-hak narapidana.

e. Pembatasan atau pengetatan remisi untuk narapidana tertentu seperti yang tercantum dalam Peraturan Pemerintah Republik Indonesia Nomor 99 Tahun 2012 tentang perubahan Kedua Atas Peraturan Pemerintah Nomor 32 Tahun 1999 tentang Syarat Dan Tata Cara Pelaksanaan Hak Warga Binaan Pemasyarakatan bertentangan dengan asas equality before the law. Oleh karena itu, perlu dikaji ulang mengenai pembatasan atau pengetatan syarat remisi untuk narapidana terutama bagi narapidana dengan tindak pidana tertentu. Hal ini disebabkan karena pada dasarnya fungsi pemasyaraktan adalah pembinaan, sedangkan dengan "mempersulit" syarat remisi bagi narapidana adalah hal yang sangat bertentangan dengan fungsi pembinaan dan hak asasi manusia dalam hal ini hak-hak narapidana.

Upaya untuk menjamin keamanan di masyarakat pasca pembebasan narapidana yang mendapatkan remisi dengan model tersebut, sekaligus menilai bagaimana mantan narapidana dapat hidup dengan pribadi yang baik serta taat hukum perlu dipertimbangkan dengan penghapusan remisi yang pernah diberikan sebelumnya apabila pasca pembebasan narapidana melakukan kejahatan kembali atau disebut residive dalam jangka waktu tertentu, sehingga terdapat keseimbangan pemberian potongan hukuman dan tangggungjawab narapidana berperilaku baik di dalam kehidupan masyarakat pasca pembebasan. Oleh karena itu, jika mengulangi perbuatan maka selain melaksanakan pidana baru yang dijatuhkan juga menjalani masa remisi yang pernah diberikan sebagai tambahan pidana baru tersebut ada baiknya diintegrasikan dalam putusan pengadilan berupa remisi umum dan khusus yang pernah diberikan padanya agar dijalani juga oleh terpidana. Hal ini membutuhkan Integrated Criminal Justice System (Sistem Peradilan Pidana Terpadu) antar lembaga penegak hukum. Sistem tersebut mirip dengan sistem remisi yang diterapkan di Kanada sebagai salah satu yang disebut memiliki sistem remisi paling efektif didunia.

Standard Minimum Rules for the Treatment of Prisoners (Aturan Minimum Standar tentang Penanganan Tahanan) telah memberikan panduan bahwa narapidana secara bertahap dikembalikan kemasyarakat kembali sehingga 
dibutuhkan kerjasama dengan menjalin hubungan bersama lembaga-lembaga diluar Lembaga Pemasyarakatan. Dilihat dari perspektif hak asasi manusia, cara pembinaan narapidana yang memiliki hak berasimilasi dengan tidak mengucilkan sepenuhnya kehidupan narapidana dengan dunia luar merupakan bagian penghormatan harkat dan martabat manusia.

Persoalan pemulihan hubungan narapidana dengan masyarakat yang dilakukan sesuai tahapan pembinaan narapidana salah satunya dengan memberikan hak asimilasi serta integrasi justru ada pada tataran teknis yaitu soal kurangnya kerjasama dengan lembaga-lembaga kerja dan lembaga sosial dengan pihak Lembaga Pemasyarakatan dan pihak ketiga atau pihak luar yang masih sulit menerima narapidana untuk ikut bekerja dalam lembaga/ usahanya. Untuk mengatasi hal tersebut, ada beberapa hal yang bisa dijadikan solusi masalah antara lain, pertama, meningkatkan kerjasama dengan pihak ketiga baik lembaga usaha maupun lembaga sosial untuk kerja soaial yang dapat digunakan sebagai tempat narapidana melaksanakan asimilasi. Kedua, melaksanakan asimilasi di kantor pemerintah, Badan Usaha Milik Negara atau Badan Usaha Milik Daerah arau lembaga pemerintah lainnya. Lembaga pemerintah yang menampung narapidana yang melaksanakana asimilasi di luar Lembaga Pemasyarakatan akan memberikan contoh bagi lembaga swasta lain bersedia menampung narapidana yang sedang melaksanakan asimilasi. Ketiga, menyiapkan lembaga khusus, baik lembaga sosial maupun lembaga pelatihan kerja yang dibuat pemerintah seperti Balai Latihan Kerja (BLK) yang tidak hanya membina narapidana di dalam Lembaga Pemasyarakatan tetapi juga di luar lembaga pemasyarakatan untuk narapidana yang memang telah memenuhi syarat.

Pembatasan yang dilakukan terhadap narapidana atas tindak pidana tertentu tersebut telah menghilangkan kesempatan berasimilasi, hal ini tentu saja tidak sesuai dengan Standard Minimum Rules for the Treatment of Prisoners (Aturan Minimum Standar tentang Penanganan Tahanan) yang jelas-jelas menyatakan bahwa narapidana secara bertahap perlu disiapkan kembali ke masyarakat dengan langkah-langkah pra pembebasan antara lain melalui Pembebasan Bersyarat (Parole). Narapidana yang tidak pernah diberikan kesempatan keluar Lembaga Pemasyarakatan akan terus terkekang meskipun telah memperbaiki diri dengan baik dan tidak pernah melakukan pelanggaran sehingga mudah merasa tersisihka / dikucilkan dari kehidupan masyarakat luar.

\section{Penutup}

Perlindungan Hak Asasi Manusia tidak saja bermakna sebagai jaminan negara pro aktif memproteksi Hak Asasi Manusia dalam pelbagai kebijakan 
regulasi, tetapi juga reaktif bereaksi cepat melakukan tindakan hukum apabila terjadi pelanggaran Hak Asasi Manusia, karena hal tersebut merupakan indikator negara hukum. Jika dalam suatu negara, Hak Asasi Manusia terabaikan atau dilanggar dengan sengaja dan penderitaan yang ditimbulkan tidak dapat diatasi secara adil, maka negara tersebut tidak dapat disebut sebagai negara hukum dan demokrasi dalam arti sesungguhnya. ${ }^{14}$

Remisi dan asimilasi adalah hak narapidana yang mendukung tercapainya tujuan sistem pemasyarakatan sebagai pelaksana pidana penjara. Remisi dan asimilasi juga sejalan dengan Internasional Covenant on Civil dan Political Rights, Body Of Principles For The Protection of Persons Under Any Form Of Detention or Imprisonment, Standard Minimum Rules For The Treatment Of Prisoners sebagai bentuk perlindungan hak asasi manusia narapidana untuk membina narapidana. Akan tetapi, pengaturan remisi di Indonesia saat ini masih tersebar dalam beberapa aturan dan tidak menjadi satu aturan yang komprehensif. Selain itu, pengetatan dengan pemberian syarat khusus terhadap narapidana tindak pidana tertentu yang diatur dalam Pasal 34A Peraturan Pemerintah Nomor 99 Tahun 2012 justru mengandung masalah pertentangan antar norma hukum sendiri, dan dalam memberi masalah hilangnya kesempatan dan persamaan yang sama di depan hukum hal mana merupakan hak asasi manusia yang harus dilindungi termasuk bagi narapidana. Ada ganjalan serius, apakah masyarakat percaya dan bersedia menerima kembali mereka, hidup, bekerja, dan bermasyarakat sebagaimana aktifitas hidup komunitasnya. Konsep integrasi sosial sesungguhnya adalah proses pembinaan yang sifatnya interaktif dan bergerak diantara terpidana/narapidana - petugas - masyarakat. Ketiga unsur itu harus bergerak secara simultan yang secara keseluruhan berorientasi pada pengentasan terpidana kembali ketengah tengah masyarakat. ${ }^{15}$

Penguatan peran remisi dan asimilasi bukan hanya sebagai hak narapidana namun juga sebagai alat untuk memberikan motivasi sekaligus penghargaan bagi narapidana yang telah sungguh-sungguh memperbaiki remisi dan asimilasi dengan melihat latar belakang tindak pidanannya yang pada kenyataannya justru menghilangkan nilai-nilai kemanusiaan sebagai landasan hak asasi manusia terlebih lagi mereka yang benar-benar lebih memperbaiki diri. Oleh karena itu, Pemerintah perlu segera membuat pengaturan khusus remisi yang komprehensif dalam suatu aturan sehingga tidak lagi terjadi jenis remisi tertentu yang ditemukan disatu aturan tapi tidak diatur diaturan yang lain. Aturan khusus

${ }^{14}$ Suparman Marzuki, Tregedi Politik Hukum HAM, Pustaka Pelajar bekerja sama dengan PUSHAM UII Yogyakarta, Yogyakarta, 2011, hlm 11.

15 Suparman Marzuki, "Efektifitas Pemidanaan Sistem Pemasyarakatan: Beberapa Kritik", Jumal Hukum No. 4 Vol. 2, Universitas Islam Indonesia, 1995, hlm 27-28. 
remisi tersebut harus mencakup seluruh hal tentang remisi baik jenis remisi, besaran remisi, kapan diberikannya, syarat-syaratnya serta prosedur sederhana dan pejabat yang berwenang memberikannya. Kementerian Hukum dan Hak Asasi Manusia dan Unit Pelaksana Teknisnya yaitu Lembaga Pemasyarakatan perlu meningkatkan kerja sama dengan pihak ketiga di bidang kerja dan ketrampilan maupun lembaga sosial, sehingga asimilasi yang ditujukan untuk membaurkan narapidana dengan masyarakat luar dapat dilaksanakan. Selain itu, perlu melibatkan lembaga pemerintah daerah untuk menampung asimilasi narapidana diluar lapas agar tidak tergantung dengan pihak swasta guna mendukung proses asimilasi.

\section{Daftar Pustaka}

\section{Buku}

Asshiddiqie, Jimly dan Hafid Abbas, Hak Asasi Manusia dalam Konstitusi Indonesia, Kharisma Putra Utama, Cetakan ke- 5, Jakarta, 2015.

Marzuki, Suparman, Tregedi Politik Hukum HAM, (Yogyakarta: Pustaka Pelajar bekerja sama dengan PUSHAM UII Yogyakarta, Yogyakarta, 2011.

Pangaribuan, Luhut, Hukum Acara Pidana: Surat Resmi Advokat di Pengadilan, Papas Sinar Sinanti, Jakarta, 2013.

Priyatno, Dwidja, Sistem Pelaksanaan Pidana Penjara di Indonesia, PT. Refika Aditama, Bandung, 2006.

Zaidan, M.Ali, Menuju Perubahan Hukum Pidana, Sinar Grafika, Jakarta, 2015.

Jurnal

Suparman Marzuki, "Efektifitas Pemidanaan Sistem Pemasyarakatan: Beberapa Kritik", Jumal Hukum, No. 4 Vol. 2, Universitas Islam Indonesia, 1995.

\section{Peraturan Perundang-undangan}

Undang-Undang Nomor 12 Tahun 1995 Tentang Pemasyarakatan, Lembaran Negara Republik Indonesia Tahun 1995 Nomor 77, Tambahan Lembaran Negara Republik Indonesia Nomor 3614.

Undang-Undang RI Nomor 39 Tahun 1999 Tentang Hak Asasi Manusia. Lembaran Negara Republik Indonesia Tahun 2009 Nomor 147. Tambahan Lembaran Negara Republik Indonesia Nomor 5066.

Undang-Undang Nomor 12 Tahun 2005 tentang tentang Pengesahan International Covenant On Civil And Political Rights (Kovenan Internasional Tentang Hak-Hak Sipil Dan Politik). Lembaran Negara Republik Indonesia Tahun 2005 Nomor 119. Tambahan Lembaran Negara Republik Indonesia Nomor 4558.

Undang-Undang Nomor 35 Tahun 2009 tentang Narkotika.

Peraturan Pemerintah Nomor 31 Tahun 1999 Tentang Pembinaan dan Pembimbingan Warga Binaan Pemasyarakatan, Lembaran Negara 
Republik Indonesia Tahun 1999 Nomor 68, Tambahan Lembaran Negara Republik Indonesia Nomor 3845.

Peraturan Pemerintah Nomor 32 Tahun 1999 Tentang Syarat dan Tata Cara Pelaksanaan Hak Warga Binaan Pemasyarakatan, Lembaran Negara Republik Indonesia Tahun 1999 Nomor 69, Tambahan Lembaran Negara Republik Indonesia Nomor 3846.

Peraturan Pemerintah Nomor 99 Tahun 2012 tentang Perubahan Kedua Peraturan Pemerintah Nomor 32 Tahun 1999 tentang Syarat dan Tata Cara Pelaksanaan Hak Warga Binaan Pemasyarakatan. Tambahan Lembaran Negara Republik Indonesia Tahun 2012 Nomor 225.

Keputusan Presiden Nomor 174 Tahun 1999 tentang Remisi. Lembaran Negara Republik Indonesia Tahun 1999 Nomor 223.

Peraturan Menteri Hukum dan Hak Asasi Manusia Nomor 3 Tahun 2018 tentang Syarat Dan Tata Cara Pemberian Remisi, Asimilasi, Cuti Mengunjungi Keluarga, Pembebasan Bersyarat, Cuti Menjelang Bebas, Dan Cuti Bersyarat.

Surat Edaran Mahkamah Agung RI Nomor 4 Tahun 2011 tentang Perlakuan bagi Pelapor Tindak Pidana (Wistleblower) dan Saksi Pelaku yang Bekerjasama (Justice Collaborators) di dalam Perkara Tindak Pidana Tertentu

Keputusan Menteri Hukum dan HAM Nomor 10 Tahun 2020 tentang Syarat Pembebasan Asimilasi dan Hak Integrasi Bagi Narapidana dan Anak Dalam Rangka Pencegahan dan Penanggulangan Penyebaran Covid-19 